\title{
KADAR KALIUM SERUM PADA LATIHAN FISIK INTENSITAS RINGAN MAHASISWA FAKULTAS KEDOKTERAN UNIVERSITAS SAM RATULANGI
}

\author{
${ }^{1}$ Yunita M. Umboh \\ ${ }^{2}$ dr. Michaela E. Paruntu \\ ${ }^{2}$ dr. Stefana H. M. Kaligis \\ Bagian Biokimia Fakultas Kedokteran Universitas Sam Ratulangi \\ Email: umbohyunita@ymail.com
}

\begin{abstract}
Potassium is one of the three highest concentration electrolytes in sweat. This is defined as the greater the rate of sweat excreation is, the greater the rate of potassium lost will be. Lossing sweat may occur while doing physical activity. The purpose of this study is to find differences in serum potassium levels before and after light intensity exercise in the student year 2010 in Faculty of Medicine Sam Ratulangi University. Thirty students, taken by purposive sampling method, were participate as samples in this study. Results showed the mean serum potassium levels before exercise was $4,0933 \mathrm{mEq} / \mathrm{L}$ and after exercise was 4,3267 mEq/L. Analysis using paired-samples t-test showed significant result $(\mathrm{p}=0,001)$. Based from results, it can be concluded that there is a significant different between serum potassium level before and after light intensity exercise.
\end{abstract}

Key Words: Serum potassium, light intensity physical exercise, students

\begin{abstract}
Abstrak:Kalium adalah salah satu dari tiga elektrolit dalam keringat dengan konsentrasi terbesar. Hal ini berarti semakin besar laju pengeluaran keringat maka laju kehilangan kalium juga akan semakin besar. Kehilangan keringat dapat terjadi antara lain saat melakukan aktifitas fisik. Penelitian ini dilakukan untuk mengetahui apakah ada perbedaan kadar kalium serum sebelum dan sesudah latihan fisik intensitas ringan pada mahasiswa Fakultas Kedokteran Universitas Sam Ratulangi angkatan 2010. Sampel dalam penelitian ini berjumlah 30 orang yang diambil menggunakan metodepurposive sampling. Hasil penelitian menunjukkan nilai rata-rata kadar kalium serum sebelum aktifitas fisik adalah 4,0933 dan sesudah adalah 4,3267. Hasil analisis menggunakan paired-samples t-test menunjukkan nilai hasil yang signifikan $(\mathrm{p}=0,001)$. Berdasarkan hasil analisis dapat ditarik kesimpulan terdapat perbedaan yang signifikan antara kadar kalium serum sebelum dan sesudah latihan fisik intensitas ringan.
\end{abstract}

Kata Kunci: Kadar kalium serum, latihan fisik intensitas ringan, mahasiswa

Kalium merupakan salah satu ion dari elektrolit bermuatan positif (kation) utama yang terdapat dalam cairan intraseluler. ${ }^{1}$ Jumlah konsentrasi kalium pada orang dewasa sekitar 50-60 per kilogram berat badan yang dipengaruhi oleh jenis kelamin, umur dan masa otot seseorang. ${ }^{1,2}$ Kalium merupakan garam yang dapat diserap dengan cepat oleh tubuh,kelebihan kalium yang terdapat dalam tubuh akan dikeluarkan lewat urin dan keringat. Saat seseorang melalukan aktivitas fisik sumber-sumberyang adadalam tubuh seperti lemak atau karbohidratakan mengalami metabolisme yang hasil akhirnya adalah air $\left(\mathrm{H}_{2} \mathrm{O}\right)$, karbon dioksida $\left(\mathrm{CO}_{2}\right)$ dan energi. ${ }^{1,3}$ 
Latihan fisik adalah gerakan yang direncanakan, terstruktur dan berulang untuk memelihara kesehatan tubuh. ${ }^{4}$ Pada waktu berolahraga energi dan panas meningkat melalui proses metabolisme dan kontraksi otot, juga air yang keluar melalui keringat tidak hanya melalui proses metabolisme tetapi hal ini didapatkan melalui konsumsi cairan dan makanan sehari-hari. ${ }^{3}$ Menurut World Health Organization (WHO) orang yang kurang aktif dalam melakukan latihan fisik mempunyai 20\% sampai 30\% peningkatan risiko terhadap semua penyebab kematian dibandingkan dengan mereka yang terlibat dalam 30 menit aktivitas fisik dengan intensitas sedang yang dilakukan hampir setiap hari dalam seminggu. ${ }^{5}$

Dalam melakukan latihan fisik bisa terjadi perubahan pada nilai mineral sesuai dengan intensitas dan durasi latihan. ${ }^{6}$ Kalium adalah salah satu dari tiga elektrolit dalam keringat dengan konsentrasi terbesar sehingga dengan semakin besar laju pengeluaran keringat maka laju kehilangan kalium dalam tubuh juga akan semakin besar. ${ }^{1}$

Latihan fisik dan olahraga sangatlah penting bagi tubuh manusia untuk meningkatkan kebugaran. Semakin meningkatnya kemajuan teknologi membuat manusia melakukan aktifitas dengan mudah. Gaya hidup yang kurang beraktifitas pada mahasiswa seperti padatnya jadwal perkuliahan dan sering duduk dibandingkan dengan sering beraktifitas fisik contohnya mahasiswa Fakultas Kedokteran Umum Universitas Sam Ratulangi didapatkan banyak mahasiswa yang mempunyai aktifitas fisik ringan dengan presentasi 96,6\% juga mahasiswa yang melakukan aktifitas sedang didapkan dengan presentasi 3,4\%. ${ }^{7,8}$

\section{METODE PENEITIAN}

Penelitian ini adalah penelitian pra-eksperimentaldengan pendekatan onegroup pretest-posttest.Penelitian dilaksanakan pada bulan September 2013 - Januari 2014. Lokasi penelitian di tempat fitness dan pemeriksaan darah dilakukan di Laboratorium. Populasi penelitian adalah mahasiswa Fakultas Kedokteran Universitas Sam Ratulangi program studi pendidikan dokter umum angkatan 2010 berjumlah 280 orang.Tapi, biasanya untuk penelitian eksperimental, sudah ditetapkan sampel minimal 30.Kriteria inklusi: 1) Sehat 2) Bukan atlet 3)Bersedia ikut dalam penelitian. Kriteria eksklusi: 1) Sedang sakit ketika latihan fisik dilakukan, 2) Mengonsumsi obat yang mempengaruhi kadar elektrolit darah (kortikosteroid, NSAID, estrogen, androgen, obat hipertensi, diuretik, dan lain-lain), 3) Mengkonsumsi makanan dan minuman 3-4 jam sebelum latihan dilakukan.4) Melakukan latihan fisik pada hari pelaksanaan penelitian. Sampel diambildenganmetode purposive samplingyang memenuhi kriteria inklusi dan eksklusi.

Metode yang digunakan ISE (Ion Selective Electrode). Ion Selective Electrode merupakan metode yang dipakai untuk mengukur perbedaan potensial elektrik antara dua elektroda. Data diolah menggunakan program SPSS dengan analisis univariatdan bivariat dengan uji t berpasangan (paired t-test).

\section{HASIL PENELITIAN}

Penelitian ini menggunakan sampel sebanyak 30 orang responden yang terdiri dari laki-laki dan perempuan mahasiswa Fakultas Kedokteran Program Studi Pendidikan Dokter angkatan 2010. Dilakukan analisis data dengan menggunakan Shapiro-wilk dan data diperoleh berdistribusi normal.

Tabel 1. Tes normalitas data

\begin{tabular}{lccc}
\hline & & Shapiro-Wilk & Sig. \\
\hline SebelumPenelitian & Statistc & df & .721 \\
SesudahPenelitian & .976 & 30 & .755 \\
\hline
\end{tabular}


Karakteristik responden yang dikelompokkan berdasarkan jenis kelamin, yaitu data yang diperoleh bahwa responden sebagian besar adalah laki-laki sebanyak 60\% (18 orang) sedangkan responden perempuan sebanyak 40\% (12 orang).Hasil penelitian kadar kalium sebelum latihan intensitas ringan, mean menunjukkan nilai 4.0933, median 4.1000, dan modus 4.20. Standart deviasi adalah 0.38501. Nilai minimum data yaitu 3.40 dan maximum yaitu 5.10.Kadar kalium sesudah latihan intensitas ringan didapatkan, mean adalah 4.3267, median adalah 4.4000, dan modus adalah 4.20. Standart deviasi adalah 0.36760. Nilai minimum yaitu 3.50 dan maximum yaitu 5.20.

Table 2. Analisis univariat

\begin{tabular}{|c|c|c|c|}
\hline & & SebelumPenelitian & SesudahPenelitian \\
\hline \multirow[t]{2}{*}{$\mathrm{N}$} & Valid & 30 & 30 \\
\hline & Missing & 0 & 0 \\
\hline \multicolumn{2}{|c|}{ Mean } & 4.0933 & 4.3267 \\
\hline \multicolumn{2}{|c|}{ Median } & 4.1000 & 4.4000 \\
\hline \multicolumn{2}{|c|}{ Mode } & $4.20^{\mathrm{a}}$ & $4.20^{\mathrm{a}}$ \\
\hline \multicolumn{2}{|c|}{ Std. Deviation } & .38501 & .36760 \\
\hline \multicolumn{2}{|c|}{ Minimum } & 3.40 & 3.50 \\
\hline \multicolumn{2}{|c|}{ Maximum } & 5.10 & 5.20 \\
\hline
\end{tabular}

Berdasarkan analisis dengan paired samples t-test didapatkan hasil terdapat perbedaan yang signifikan antara kadar kalium sebelum dan sesudah latihan intensitas ringan $(p=0.001)$.

Table 3. Analisis bivariat

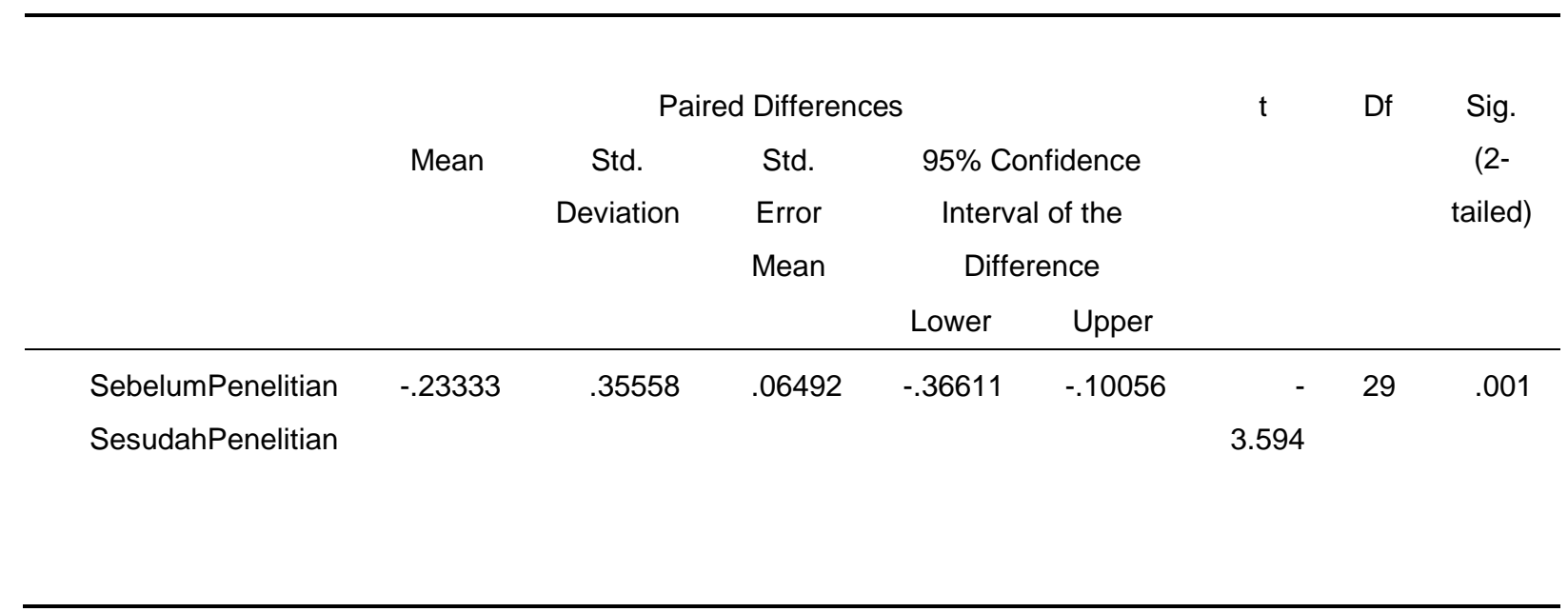




\section{BAHASAN}

Berdasarkan hasil penelitian, terdapat perbedaan mean kadar kalium sebelum dan sesudah latihan fisik intensitas ringan. Perbedaan ini dapat disebabkan oleh insensible water lossyaitu melalui penguapan dari paru-paru dan kulit. Teori menyatakan hilangnya air melalui keringat rendah pada keadaan basal tapi meningkat bermakna saat latihan atau meningkat saat suhu lingkungan yang tinggi. ${ }^{9}$

Berdasarkan hasil analisis bivariat didapatkan terdapat perbedaan yang signifikan antara kadar kalium sebelum dan sesudah latihan fisik intensitas ringan. Hal ini berbeda dengan penelitian dari Hazar et al dan Koc yang menunjukkan tidak ada perbedaan yang signifikan pada penelitian yang dilakukan dalam latihan intensitas sedang dan berat.

Terdapat dua perbedaan dalam penelitian antara peneliti dengan penelitian dari Hazar et al dan Koc. Pertama terdapat perbedaan pada sampel penelitian. Penelitian sampel peneliti adalah non atlit sedangkan Koc dan Hazar dilakukan pada atlit. Seorang atlit biasanya telah mengalami aklimatisasi terhadap panas tubuh melalui peningkatan pemaparan atletik yang progresif selama lebih dari 1 sampai 2 minggu dibandingkan dengan melakukan latihan atletik secara maksimum pada hari pertama latihan. Kelenjar keringat juga mengalami aklimatisasi sehingga jumlah kehilangan garam dalam keringat menjadi sedikit dibandingkan dengan sebelum beraklimatisasi. ${ }^{10}$

Kedua terdapat perbedaan dalam aktifitas fisik termasuk intensitas dan durasi latihan. Koc dan Hazar melakukan latihan intensitas yang sedang dan berat dengan durasi lebih dari 30 menit sedangkan peneliti melakukan latihan intensitas ringan dengan durasi 30 menit. Hal ini dapat disebabkan karena pada non atlit laju pengeluaran keringat lebih banyak dibandingkan dengan atlit meskipun hanya melakukan aktifitas fisik intensitas ringan dalam waktu yang relatif singkat, sedangkan pada atlit karena proses aklimatisasi laju pengeluaran keringat telah mengalami adaptasi. Pada atlit juga biasanya telah mendapatkan asupan nutrisi (dalam hal ini kalium) agar performa tetap terjaga ${ }^{3}$ sehingga tidak terdapat perbedaan yang signifikan.

Penelitian ini mempunyai beberapa keterbatasan antara lain dalam jumlah sampel. Jumlah sampel yang diambil adalah jumlah sampel minimal yang diperlukan dalam penelitian eksperimental. Agar hasil penelitian dapat lebih baik lagi sebaiknya jumlah sampel dihitung menggunakan rumus Slovin (berdasarkan populasi). Kelemahan lain dalam penelitian ini adalah tidak dapat menjaga suhu ruangan. Hal ini dapat berpengaruh pada hasil karena suhu lingkungan dapat mempengaruhi laju pengeluaran keringat.

\section{SIMPULAN}

Dalam penelitian ini peneliti menarik kesimpulan bahwa dalam melakukan latihan fisik intensitas ringan terdapat perbedaan kadar kalium serum yang signifikan antara sebelum dan sesudah latihan intensitas ringan.

\section{DAFTAR PUSTAKA}

1. Irawan MA. Cairan tubuh, elektrolit \& mineral [homepage on internet]. 2007 [cited 2013 Sep 13]. Available from: http://www.pssplab.com/journal/01.pdf.

2. Yaswir R, Ferawati I. Fisiologi dan gangguan keseimbangan natrium, kalium, dan klorida serta pemeiksaan laboratoium. JKA. 2012; 1: 80-5.

3. Irawan MA. Konsumsi cairan \& olahraga [homepage on internet]. 2007 [cited 2013 Sep 13]. Available from: http://www.pssplab.com/journal/02.pdf. 
4. Sjostrom M, Ekelund U, Ynvge A. Pengkajian aktivitas fisik. in: Widyastuti P, Hardiyanti EA, editor bahasa indonesia. Gizi kesehatan masyarakat. Hartanto A, alih bahasa. Jakarta: EGC, 2008; p.100-8.

5. World Health Organization. Prevalence of insufficient physical activity [homepage on internet][cited 2013 Okt 23]Available from: http://www.who.int/gho/ncd/risk_factors/physical_activity_text/en/.

6. Hazar M, Sever O, Gurkan CA, Er FN, Erol M. Physiologic responses of macro elements to maximal aerobic exercise in male and female footballers. Life Sci J. 2013;10(6): 734-7

7. Depkes RI. Panduan kesehatan olahraga bagi petugas kesehatan [Homepage on internet]. 2002 [cited 2013 Nov 20]. Available from: http://www.depkes.go.id/

8. Thirtayasa HI. Hubungan antara aktivitas fisik dengan status gizi mahasiswa angkatan 2011 program studi pendidikan dokter universitas sam ratulangi. Manado. Fakultas Kedokteran Universitas Sam Ratulangi, 2012.

9.Wilson LM. Keseimbangan cairan dan elektrolit serta penilaiannya. In: Hartanto H, Susi N, Wulansari P, Mahanani DA, editor bahasa Indonesia. Patofisiologi konsep klinis proses-proses penyakit (Edisi 6). Pendit BU, Hartanto H, Wulansari P, Mahanani DA, alih bahasa. Jakarta: EGC, 2005; p.308-9, 313, 341-3.

10. Guyton AC, Hall JE. Buku Ajar Fisiologi Kedokteran (Edisi 11). In: Racman LY, Wahyunigsih E, Yulianti E, Karyuni PE, editor bahasa Indonesia. Jakarta: EGC, 2007; p.307-15, 385, 1122. 